Working Paper/Document de travail 2011-6

\title{
The Private Equity Premium Puzzle Revisited
}

by Katya Kartashova 
Bank of Canada Working Paper 2011-6

February 2011

\title{
The Private Equity Premium Puzzle Revisited
}

\author{
by \\ Katya Kartashova \\ Canadian Economic Analysis Department \\ Bank of Canada \\ Ottawa, Ontario, Canada K1A 0G9 \\ kkartashova@bankofcanada.ca
}

Bank of Canada working papers are theoretical or empirical works-in-progress on subjects in economics and finance. The views expressed in this paper are those of the author.

No responsibility for them should be attributed to the Bank of Canada. 


\section{Acknowledgements}

I am grateful to my advisor Narayana Kocherlakota for his continued guidance and encouragement throughout this project. I am very thankful to Brian Bucks for sharing his expertise on SCF, and to Gerhard Fries for answering data inquiries on SCF. I thank Dick Todd and Martin Schneider for very helpful discussions and Mallory Leung for her contribution at the early stages of this project. I also thank Laurence Ales, Frederico Belo, Nick Guo, and Annette Vissing-Jørgensen for helpful suggestions. I am grateful to the staff of the Thomson Reuters Helpdesk, who worked tirelessly on my inquiries regarding the SDC Platinum database, and the members of the Data Team, who helped resolve discrepancies in the data. I thank Joan Gieseke for excellent editorial assistance. All remaining errors are mine alone. 


\begin{abstract}
In this paper, I extend the results of Moskowitz and Vissing-Jørgensen (2002) on the returns to entrepreneurial investments in the United States. First, following the authors' methodology I replicate the original findings from the Survey of Consumer Finances (SCF) for the period 1989-1998 and show that the returns to private and public equity are similar. I then extend the period under consideration using data from subsequently released waves of SCF 2001, 2004, and 2007 and assess the robustness of their results to this extension. I find that the "private equity premium puzzle" is not a robust feature of the data and does not survive beyond the period of high public equity returns in the 1990s. In particular, returns to entrepreneurial equity remain largely unaffected when public equity returns plunge to near zero values between 1999 and 2001. The average return to private equity exceeds public equity return in 1999-2007 and for the period 1989-2007 as a whole. To validate the results, I provide alternative measures of private equity returns in the data.
\end{abstract}

JEL classification: G11, G12, G24, G31, G32

Bank classification: Financial markets; Recent economic and financial developments; Interest rates

\title{
Résumé
}

L'auteure applique à une plus longue période la méthode qu'utilisent Moskowitz et Vissing-Jørgensen (2002) pour calculer le rendement des investissements des entrepreneurs américains. En premier lieu, en suivant la même approche qu'eux, elle reproduit les résultats initiaux obtenus à partir de l'enquête sur les finances des consommateurs pour les années 1989 à 1998 et montre que les entreprises à capitaux privés et les sociétés cotées en bourse offraient alors des rendements similaires. L'auteure prolonge ensuite la période étudiée en exploitant les données publiées des éditions 2001, 2004 et 2007 de l'enquête, puis évalue si les résultats de Moskowitz et Vissing-Jørgensen tiennent toujours. L’énigme que posait la trop faible prime de risque sur les capitaux privés ne constitue plus un trait caractéristique des données une fois disparus les forts rendements boursiers des années 1990. En particulier, les rendements des capitaux des entrepreneurs restent largement inchangés lorsque les rendements en bourse dégringolent pour devenir quasi nuls entre 1999 et 2001. Le rendement moyen des capitaux privés dépasse celui des placements boursiers de 1999 à 2007 et durant toute la période 19892007. Pour valider les résultats, l'auteure fournit d'autres mesures statistiques des rendements produits par les capitaux privés.

Classification JEL : G11, G12, G24, G31, G32

Classification de la Banque : Marchés financiers; Évolution économique et financière récente; Taux d'intérêt 


\section{Introduction}

In this paper, I extend the results of Moskowitz and Vissing-Jørgensen (2002) on the returns to entrepreneurial investments in the United States. First, I replicate the set of findings in Moskowitz and Vissing-Jørgensen (2002) (also referred to as MVJ) using the authors' methodology and data from the four Surveys of Consumer Finances (SCF) available for the period from 1989 to 1998. Then I incorporate into my analysis subsequently released waves of SCF 2001, 2004, and 2007 and assess the robustness of their original findings to this extension of the period under consideration.

I find that the "private equity premium puzzle" documented by Moskowitz and Vissing-Jørgensen (2002) is not a robust feature of the data and does not survive beyond the 1990s, a period of extraordinarily high public equity returns. In the new sample period, entrepreneurial portfolios remain poorly diversified, ${ }^{1}$ but entrepreneurial equity significantly outperforms public equity. In particular, in 1999-2001 the average annualized public equity returns fall to near zero values, while returns to entrepreneurial equity remain largely unaffected. Public equity returns also remain substantially below their private equity counterparts in the period 2002 to 2004. This is in sharp contrast to the original finding of Moskowitz and Vissing-Jørgensen (2002) that private equity returns are no higher than returns to public equity over the period 1989-1998.

This relative performance across the two sample periods mirrors the behavior of public and private equity values, as they mechanically account for the largest part of the returns. The two equities grow at a similar rate throughout the 1990s and so their average returns are very close over the period 1989-1998. In the new sample period, the growth rate of public equity falls due to large negative capital gains in the early 2000s. At the same time, private equity continued to increase in value steadily earning higher average return relative to public equity for the period 1998-2007, and 1989-2007 as a whole. As a robustness check for my findings, I consider alternative measures of private equity returns - in particular, the private equity industry returns.

The paper is organized as follows. Section 2.1 reports on the extended series for the returns to public and private equity for the period 1989 to 2007, with particular focus on the aftermath of the 1990s. Section 2.2 includes a brief discussion of the post 2007 events and data issues involved. Section 3 discusses one of the approaches to validate reported results, and Section 4 concludes.

\section{Performance of Private and Public Equity Beyond 1989-1998}

Private equity refers to non-traded owner's capital and shareholders' equity. This is the equity held both in non-traded unincorporated businesses such proprietorships and partnerships, ${ }^{2}$ and in incorporated businesses such as subchapter $\mathrm{S}$ and $\mathrm{C}$ corporations. In turn, public equity refers to direct and indirect share holdings in publicly traded companies. In this section, I report the extended series for the returns to public and private equity and the underlying aggregate statistics, focusing on the period beyond 1998 .

\subsection{Aggregate Returns to Private and Public Equity}

I follow the methodology of Moskowitz and Vissing-Jørgensen (2002) to replicate returns to an index of private equity for the period 1989-1998 and to extend the series to 2007. Regular SCFs are cross-sectional surveys and are carried out triennially. Figure 1 shows data used in the construction of average annualized returns $^{3}$ over these three-year intervals; for conceretenss I use the example of two consecutive SCF surveys in 1989 and 1992. The market value of equity is reported for the year of the survey, and the value of profits (net income) refers to the year preceding it.

\footnotetext{
${ }^{1}$ See Table 5 for a comparison of statistics on the concentration of entrepreneurial investments in their firms and public equity ownership concentration for SCF 1995, 2004, and 2007. Table 6 also provides summary statistics on entrepreneurs from the SCF 1995 and 2007.

${ }^{2}$ More specifically, unincorporated businesses include such legal forms of organizations as general partnerships, limited partnerships, including limited liability and limited liability limited partnerships, and limited liability companies, etc.

${ }^{3}$ The same formula applies to both raw and adjusted returns, with appropriate changes to market value of equity and net income used in the calculation.
} 
Figure 1: Computing Returns to an Index of Private Equity

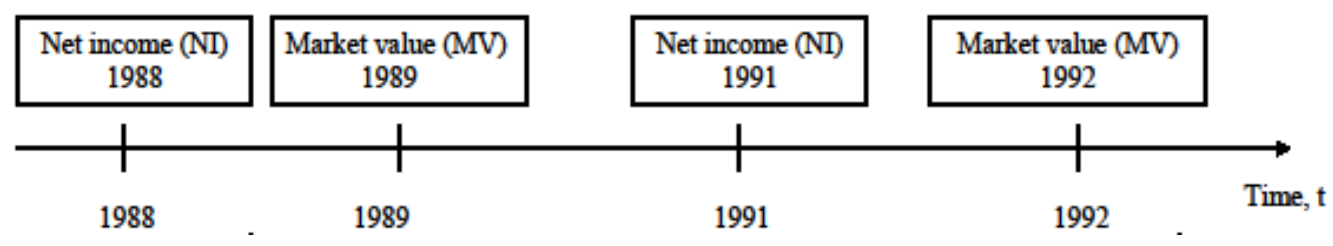

Using data in Figure 1, the average annualized return $R$ over the period 1989-1992 is computed as the geometric average of returns $R_{1}$ and $R_{2}$ as follows:

$$
\begin{aligned}
R_{1} & =\left(\frac{\mathrm{MV}_{1992}+3 \cdot \mathrm{NI}_{1988}}{\mathrm{MV}_{1989}}\right)^{\frac{1}{3}} \\
R_{2} & =\left(\frac{\mathrm{MV}_{1992}+3 \cdot \mathrm{NI}_{1991}}{\mathrm{MV}_{1989}}\right)^{\frac{1}{3}} \\
R & =\left(\sqrt{R_{1} \cdot R_{2}}-1\right) \cdot 100 \%
\end{aligned}
$$

The values of market equity and net income depend on an index of private equity, for which returns are being constructed, for example, an index of corporate, non-corporate or total private equity. The underlying statistics for the computation of the returns are reported in Table 1 (additional details on these statistics in SCF and other sources of aggregate data are included in Appendix A).

Table 2 summarizes the returns to public and private equity for the period 1989-2007. Reported in lines 1-3 of the table are the raw returns to an index of all private equity, and to indices of corporate and noncorporate private equity constructed using (1)-(3) above. In the remainder of the table, I report raw returns with adjustments in stages for $(i)$ the profit tax; (ii) retained earnings; (iii) labor income of entrepreneurs managing their own businesses; ${ }^{4}(i v)$ firm birth and new equity investment; and $(v)$ the turnover of firms through IPO, mergers and acquisitions, and liquidation. These adjustments apply both to the market value of equity (MV) and to net income (NI) in (1)-(2). Lines 7-24 provide a comparison for the period 1989-1998 of replicated returns and returns reported in MVJ after each stage of adjustment. The MVJ returns are reported in parentheses, and replicated returns to all private equity and corporate/noncorporate equity mirror them very closely. ${ }^{5}$ The final returns to all private equity are reported in lines 25 and 26 (the MVJ returns) of Table $2 .{ }^{6}$ For the benchmark comparison with public equity returns, I use the CRSP market index return reported in line 30 of Table 2. This is a value-weighted portfolio return for all available stocks in the trading period. ${ }^{7}$ The number reported for each three-year period is the geometric average of the annual returns aggregated from the monthly returns in CRSP. Appendix B discusses alternative measures of public equity returns.

In the original period 1989-1998, returns to indices of private and public equity appear to co-move closely. The returns to an index of all private equity are also no higher than the returns to public equity. However, with the extension of the period under consideration into the 2000s, the close co-movement of the returns weakens, so that private equity displays a substantial premium over public equity, in particular, due to its low returns in 1999-2001. Over this period, the average annualized public equity returns plunge to

\footnotetext{
${ }^{4}$ Appendix D discusses the assumptions underlying the labor income adjustment in MVJ and possible alternatives.

${ }^{5}$ Replicating these results exactly would be impossible, since the SCF is edited periodically and the old versions of the survey data are replaced by the new ones. For a list of all changes to the data, see http://www.federalreserve.gov/PUBS/oss/oss2/changes.html.

${ }^{6}$ While in lines 7-24 the replicates and the original returns are quite close to each other, the difference between the two is more sizeable in lines 25 and 26, which take into account the mergers and acquisitions adjustment. The sources of this discrepancy are discussed in detail in Appendix C. Over the period 1989-2007 the contribution of the mergers and acquisitions adjustment to private equity returns has always been positive, leading to an increase in private equity returns. However, the main result of the paper remains unchanged when instead public equity returns are compared to returns in line 24 before the final adjustment for mergers and acquisitions, which are lower.

${ }^{7}$ The weights applied to the individual stock returns are given by the market value of the individual stock, outstanding at the end of the previous trading period, in the total market value of all stocks.
} 
near zero values, whereas the returns to private equity remain largely unaffected. ${ }^{8}$ Overall, this relative performance across the two sample periods mirrors the behavior of public and private equity values, as they mechanically account for the largest part of the returns. More specifically, the two equities grow at a similar rate throughout the 1990s and so their average returns are very close over the period 1989-1998. In the new sample period, however, the growth rate of public equity falls due to large negative capital gains in the early 2000s as reported in line 1 of Table 3 . At the same time, private equity continues to grow at a fairly constant rate, earning a higher average return than public equity for the period 1999-2007, and 1989-2007 as a whole.

I check the robustness of my findings using the private equity industry returns as an alternative to private equity returns in the SCF. The details for this robustness exercise are included in Section 3.

\subsection{The Current Recession and Equity Returns}

This paper extends the results of Moskowitz and Vissing-Jørgensen (2002) through the end of 2007, the year of the latest publicly available Survey of Consumer Finances. While the start of the current economic crisis also dates back to late 2007, its main developments associated with the decline in the stock market and the economic activity in the real sector did not take place until 2008-2009. Therefore, the aggregate public and private equity returns reported in Tables 2 and 3 for 2004-2007 do not reflect these later adverse developments. ${ }^{9}$

What is the effect of the current crisis on the relative performance of public and private equities? While data on public equity returns from CRSP show that they fell sharply to significantly negative values after 2007 before rebounding in 2010, similar data required for construction of private equity returns in SCF are not readily available. In July 2009 the Federal Reserve Board launched a follow-up survey of the respondents interviewed in the $2007 \mathrm{SCF}$ to document the effects of the crisis on households and their finances. At the same time, the regularly scheduled SCF survey was conducted in 2010. While the data from the 2010 SCF will be published in summary form in early 2012, it is not yet certain that it will be possible to release to the public a version of the panel micro data from 2007-2009 SCF. Thus, it is not possible to obtain an estimate of the return to private equity from SCF for the same period. As shown in the previous section, private equity substantially outperforms public equity over the period 1999-2001, which also includes the recessionary year of 2001. The nature of this recession has been quite different, however, and any comparisons with earlier recessionary episodes should be drawn with caution.

\section{Alternative Measures of Private Equity Returns: the Private Equity Industry}

The private equity industry is represented by venture capital and buyout funds, organized as partnerships and involving cooperation between entrepreneurs, financial organizers, and investors. The financial organizers and investors serve as general and limited partners in these partnerships, with entrepreneurs in their role as scientists and executives. The general partners and entrepreneurs primarily supply human capital, and receive a return on their human capital investment, ${ }^{10}$ while the limited partners provide financial capital and earn financial returns. Thus, to validate the estimates of private equity returns reported earlier, the appropriate comparison is between the return to private equity net of labor income adjustment in SCF and returns of limited partners in the private equity funds.

Thomson Reuters' database VentureXpert produces the estimate of the limited partners' pooled internal

\footnotetext{
${ }^{8}$ As reported in line 2 of Table 3, two of the three public equity returns in 1999-2001 are highly negative with the average net return for the period close to zero. Negative returns in 2002 also contribute to relatively low average return for the period 2002-2004.

${ }^{9}$ Appendix A provides a more detailed discussion of the aggregate statistics for private and public equity in SCF 2007 and their comparison with the aggregates in FFA/NIPA.

${ }^{10}$ The human capital here refers to the present discounted value of the labor input - time adjusted for effort. For entrepreneurs and general partners, the financial investment constitutes only a small part of their total investment and is taken into account.
} 
rate of return $(\mathrm{IRR})^{11}$ as a standard measure of the industry's performance. ${ }^{12}$ This return is constructed by pooling together private equity funds similar to the index of all private equity in Moskowitz and VissingJørgensen (2002). The IRR is calculated as an annualized effective compounded rate of return using net cash flows (to and from investors) and the residual value of the pooled fund. ${ }^{13}$ Prior to exit events these values are determined according to traditional valuation practices in the industry. In particular, as venture capital financing usually takes place in rounds, investments are valued as of the most recent round of financing. ${ }^{14}$ In turn, the values for non-venture or buyout funds are set at the purchase of portfolio companies. When portfolio companies exit through IPOs, mergers and acquisitions, and liquidations, the actual market values are used. Line 3 of Table 4 reports pooled IRR as a measure of private equity industry performance. These series co-move closely with the return series from SCF in line 25 of Table 2 , and yield the same qualitative comparison to public equity returns.

\section{Conclusions}

In this paper, I establish that the so-called private equity premium puzzle, orriginally identified in MVJ (2002), is not a robust feature of the data as it does not survive beyond the period of high public equity returns in the 1990s. In particular, the returns to the entrepreneurial equity index remain largely unaffected when public equity returns plunge between 1999 and 2001. This result is validated using an IRR measure of the private equity industry returns. At the same time, necessary data are not yet available to compare the performance of public and private equity in the most recent recession. As SCF public use micro data are released in 2012, the sign and size of the private equity premium can be accurately determined and incorporated into the discussion. More generally, the findings presented here may be suggestive of the role of private equity as a hedge against public equity, which is also a subject of future research.

\footnotetext{
${ }^{11}$ The internal rate of return is defined as the return at which the net present value of investment becomes 0 .

${ }^{12}$ In particular, the returns from VentureXpert have been used by Kaplan and Schoar (2005) as the aggregate measures of private equity industry performance in the 1980s and 1990s. Hall and Woodward (2007) do not use venture index returns produced by VentureXpert, but compute their own measures with data from Sandhill Econometrics using two methods. Venture index returns are obtained using two methods. First, they construct returns using company-level flows and the share of ownership of the limited investors, adjusting for preferences, dilution and GP charges. Second, they calculate returns using the net amounts directly received by limited partners. They find that the two measures move "reasonably close" to each other, and to the VentureXpert reported returns. The findings in Hall and Woodward (2007) and previous studies justify using readily available index returns from VentureXpert. I use the VentureXpert supplied return to an index of all private equity, including both venture and buyout funds, and for the two types of private equity separately.

${ }^{13}$ This residual value is treated as a terminal cash flow to investors.

${ }^{14}$ Hall and Woodward (forthcoming) discuss the endogeneity of these financing events, and propose a correction to the returns of investors that would take this endogeneity into account. They propose using linear interpolation to impute values in between rounds of financing over the regular valuation intervals.
} 


\section{$5 \quad$ References}

Antoniewicz, R.L. (2000): "A Comparison of the Household Sector from the Flow of Funds Accounts and the Survey of Consumer Finances," Working Paper 96-26, Board of Governors of the Federal Reserve System.

Hall, R.E., And S.E. Woodward (2007): "The Incentives to Start New Companies: Evidence from Venture Capital," Working paper, Hoover Institution, Stanford University.

Hall, R.E., And S.E. Woodward: The Burden of the Nondiversifiable Risk of Entrepreneurship, American Economic Review, 100(3): 1163-94.

Kaplan, S. N., And A. Schoar (2005): "Private Equity Performance: Returns, Persistence, and Capital Flows," Journal of Finance, 60 (4), 1791-1823.

McGrattan, E., and E. Prescott (2005): "Expensed and Sweat Equity," Working Paper 636, Federal Reserve Bank of Minneapolis.

Moskowitz, T.J., And A. Vissing-Jørgensen (2002): "The Returns to Entrepreneurial Investment: A Private Equity Premium Puzzle?" Americal Economic Review, 92 (4), 745-78. 


\section{Appendix A. Aggregate Statistics on Public and Private Equity: Comparison of SCF, NIPA/FFA, and CRSP}

In Table 1, I compare aggregate statistics for private and public equity using alternative sources of data. For public equity, the benchmark results in the paper use values from the Center for Research in Security Prices (CRSP). The apparent discrepancy between SCF and CRSP arises mainly from the fact that public equity values in SCF exclude some categories of indirect shareholdings in CRSP, leading to a systematic downward bias. ${ }^{15}$ An additional source of discrepancy comes from the reporting of indirectly held equities in pooled investment funds and tax-deferred retirement accounts. ${ }^{16}$ These are often invested jointly in bonds and stocks, and the split reported in SCF may not be entirely accurate.

In terms of the time series behavior, unlike in the 1990s, in the period from $1998^{17}$ to 2004 the series of public equity values in SCF appear to diverge substantially from their CRSP counterpart. ${ }^{18}$ More specifically, the value of public equity in CRSP increased slightly between 1998 and 2001, and then more dramatically between 2001 and 2004. In SCF, on the contrary, the value of public equity experienced significant growth between 1998 and 2001, and then declined somewhat between 2001 and 2004. Given these differences in the behavior of aggregate public equity values in the two sources and the fact that CRSP is the most accurate source of public equity values, I include in Table 1 the alternative series for public equity values from SCF, which uses information on the behavior of total public equity from CRSP. These series use the weighted average of equity values in 1998 and 2004 SCFs in place of the 2001 value, with the weights reflecting the fraction of the total increase in CRSP value of equity between 1998 and 2004 that occurred from 1998 to 2001. ${ }^{19}$ These alternative series are used in the computation of revised public equity returns from SCF, reported for reference in line 35 Table 2.

For private equity, I compare statistics from SCF and NIPA/FFA. The series of equity values for the corporate and non-corporate sectors track each other reasonably well in the two sources for the period 19892004. However, from 2004 to 2007 there is a large increase in the total value of private equity in SCF, largely due to an almost two-fold increase in the value of unincorporated equity. ${ }^{20}$ Noncorporate profits experienced similarly large growth in this period. More generally, comparison across the two sources reveals lower values of equity and profits for the noncorporate sector in NIPA/FFA. Among others, two main reasons might be contributing to this difference. On the one hand, FFA reports values outstanding as of end of year, and SCF interviews its respondents much earlier in the year. While not significant in other years, in 2007 these differences in valuation dates can be important with the start of the economic crisis dating back to Fall 2007. On the other hand, there is an issue with the valuation of equity in FFA/NIPA. It includes both market and non-market components. Using standard balance sheet accounting it is the sum of tangible assets (real estate at estimated market value, equipment, software, and inventories all at replacement / current) and financial assets less liabilities. At the same time, it excludes the value of intangible assets, in particular, financed with "sweat and equity investments," reported as part of the business owners'21 equity in SCF. Despite these differences, however, the returns from NIPA/FFA and SCF in Table 2 are largely comparable.

\footnotetext{
${ }^{15}$ Excluded from SCF are public equities owned by defined benefit retirement plans, including state and local government retirement plans, or by nonprofit organizations, insurance companies, etc., which constitute indirect holdings of the households. More systematically, comparison of SCF with other sources of aggregate statistics in terms of their coverage is addressed in Antoniewicz (2000).

${ }^{16}$ These include combination, stock, and other mutual funds in the pooled investment funds, and IRAs, Keogh, and certain employer-sponsored accounts in the tax-deferred retirement accounts.

${ }^{17}$ Given the procedure for construction of private equity returns, year 1998 is included in both periods - from 1989 to 1998 and from 1998 to 2007.

${ }^{18}$ The series in CRSP referred to here are also those reported over the three-year intervals.

${ }^{19}$ This is similar to the approach used by MVJ with respect to the 1995 value of profits of proprietorships and partnerships, which was very sensitive to the presence of a single observation.

${ }^{20}$ This category includes sole proprietorships, general partnerships, limited partnerships, and limited liability companies, with the LPs and LLCs responsible for the largest part of the increase. The limited liability companies and limited liability partnerships are grouped together for the public dataset. The LLC legal form of organization combines the limited liability for all owners characteristic of corporations with the pass-through tax treatment of partnerships, and offers more organizational flexibility than S-corporations. This classification is based on the incorporation status of the business at its establishment. Thus, unincorporated equity also includes the value of businesses that have elected to be treated as corporations for tax purposes.

${ }^{21}$ See McGrattan and Prescott (2005) for definitions of expensed and sweat equity investments and for the discussion of accounting issues related to these investments in NIPA/FFA.
} 


\section{Appendix B. Alternative Measures of Returns to Public Equity}

Alternative measures of public equity performance used for comparison include the CRSP S\&P holding return and Shiller's S\&P 500 index return as reported in Table 2 in lines $32^{22}$ and 33, respectively. They deliver a qualitatively similar comparison with private equity returns. I also use public equity returns from SCF in line 35 of the same table, constructed in the same way as their private equity counterparts. In particular, in their construction, the "equity" variable from the SCF public extract is used for the value of household public equity holdings, ${ }^{23}$ and the "dividend income" variable from the full dataset is used for the value of income derived from these equity holdings. ${ }^{24}$ The aggregate values for public equity and the dividend distributions are obtained by summing up the values of equity and dividend income for each household multiplied by the SCF non-response adjusted sample weights. As in the case of private equity, I report the geometric average of the two returns ( $R 1$ and $R 2$ ) computed using two alternative values of aggregate dividend income. The returns to public equity based on the revised equity series in SCF are somewhat higher than the returns obtained in CRSP, but display a large negative premium relative to private equity returns in 1999-2001 and 2002-2004.

\section{Appendix C. Mergers and Acquisitions}

Moskowitz and Vissing-Jørgensen (2002) report their most accurate estimates of private equity returns with the mergers and acquisitions adjustment. In addition to firm births and deaths through liquidations and bankruptcies, this is an important channel for changes in the aggregate value of private equity. Returns with M\&A adjustment are reported in Table 2 in lines 25 and 26, respectively. The data for this adjustment come from the SDC Platinum database of Thomson Reuters, which is the same database used by MVJ. They report that about $50 \%$ of the transactions they include in the adjustment have missing deal values in the database, and use imputation regression method to address this issue. Since the publication of their paper, however, a large number of these missing value transactions were updated to include the actual deal values. ${ }^{25}$ Thus, the difference in returns mentioned earlier may reflect the systematic downward bias created by the imputation procedure. It can also be associated with the classification of transactions by the source of financing. For the purpose of this adjustment, it is important to distinguish between debt (including internal funds) and equity financing of the mergers and acquisition. While some transactions are classified as debt or equity financed only, others use both, and so their total values have to be divided accordingly. The different numbers of transactions with debt and equity financing reported in Table 5 of Moskowitz and Vissing-Jørgensen (2002) and in Table 7 of this paper suggest that in mixed financing cases, the deal value may have been assigned to either the debt or the equity category instead of both. While these two sources would explain most of the difference between the results reported in lines 25 and 26, pure input errors may have also played a role. ${ }^{26}$ With higher private equity returns for the period 1989-1998 due to M\&A adjustment, the nature of their comparison with the public equity returns over the same period remains unchanged. ${ }^{27}$ At the same time, mergers and acquisitions produce an upward adjustment to the total private equity returns for the period 1999 to 2007 and contribute positively to the premium of private over public equity.

\footnotetext{
${ }^{22}$ As well as in line 3 of Table 3 .

${ }^{23}$ As mentioned previously, the household public equity holdings include direct holdings of stocks, mutual funds, defined contribution retirement plans, trusts, and annuities.

${ }^{24}$ The question corresponding to this variable in SCF is: "In total, what was your (family's) annual income from dividends in ... (year), before deductions for taxes and anything else?"

${ }^{25} \mathrm{SDC}$ Platinum is a commercial use database which gets updated as additional information for past transactions becomes available, in particular, for missing deal values. The database contains a special variable that records the date when the transaction was last updated. Many transactions continue to be updated many years after their effective date and the date of the original posting in the database. In particular, heavily edited fields include the total value of the deal, the sources of financing (debt or equity or both), and their values. Thomson Reuters, which owns the database, collects its data from many different sources, including prospectuses, newspapers, experts, etc., so the information may become available in parts and find its way into the database over time.

${ }^{26}$ For example, some of the acquirors/targets in SDC have been mistakenly coded as both private and public. These discrepancies and inaccuracies were corrected with the help of Thomson's Helpdesk.

${ }^{27}$ The private equity returns are no higher than the public equity returns.
} 


\section{Appendix D. Robustness Checks: Labor Income Adjustment}

The labor income adjustment removes the component of raw private equity returns that should be correctly attributed to the human capital investment of entrepreneurs, e.g., as they provide managerial and other labor services to their businesses but fail to report compensation at market rates. Sole proprietors and partners, in particular, are outrightly prohibited from expensing their own labor in their businesses, with many reporting in SCF no or zero labor compensation. In these cases, Moskowitz and Vissing-Jørgensen (2002) reduce their reported net income by the amount of imputed wages to arrive at the measure of net income used in the construction of returns. At the same time, if sole proprietors and partners do report positive labor compensation, it is assumed to be already excluded from their reported net income. There are two objections to this differential treatment of net income with non-zero labor compensation. First, for the question of net income of the business, the SCF codebook contains references to IRS income tax forms. The net income of sole proprietors and partners on these forms refers to the total net income and thus must include labour compensation. Second, in NIPA/FFA, capital and labor incomes of proprietors and partners are usually determined by dividing their total net income according to production function factor shares, which also implies that it is inclusive of labor compensation. This suggests two alternatives to the procedure in MVJ (2002) for labor income adjustment. The results for this alternative labor adjustment to the net income of proprietors and partners using (i) the total of reported and imputed unreported wages and (ii) the time-invariant labor share are reported in lines 2 and 3 of Table 8 , respectively. The main result of the paper remains unchanged when these returns are compared to CRSP public equity returns in line 4 of the table. 
Table 1: The Aggregate Statistics of Private and Public Equity (1989-2007), \$ billion

\begin{tabular}{|c|c|c|c|c|c|c|c|}
\hline Survey year & 1989 & 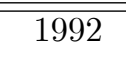 & 1995 & 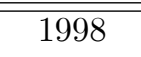 & 2001 & 2004 & 2007 \\
\hline \multicolumn{8}{|l|}{ Statistics From SCF } \\
\hline \multicolumn{8}{|l|}{ Private Equity Values } \\
\hline $\begin{array}{l}\text { Total equity }[1] \\
\text { s.e. }\end{array}$ & $\begin{array}{l}3,680 \\
(525)\end{array}$ & $\begin{array}{l}3,740 \\
(298)\end{array}$ & $\begin{array}{l}4,290 \\
(277)\end{array}$ & $\begin{array}{l}5,710 \\
(427)\end{array}$ & $\begin{array}{l}7,830 \\
(484)\end{array}$ & $\begin{array}{l}9,650 \\
(521)\end{array}$ & $\begin{array}{c}14,700 \\
(859)\end{array}$ \\
\hline Equity in PP & 2,020 & 1,980 & 1,990 & 2,510 & 3,570 & 4,310 & 8,260 \\
\hline s.e. & $(397)$ & (143) & $(174)$ & (208) & $(272)$ & (299) & (626) \\
\hline Equity in SC & 1,660 & 1,770 & 2,300 & 3,200 & 4,260 & 5,350 & 6,460 \\
\hline s.e. & $(242)$ & $(223)$ & $(241)$ & $(348)$ & $(358)$ & $(411)$ & $(560)$ \\
\hline \multicolumn{8}{|l|}{ Public Equity Values } \\
\hline Original series & 1,770 & 2,230 & 3,640 & 7,430 & 11,400 & 10,800 & 13,700 \\
\hline Revised series [2] & 1,770 & 2,230 & 3,640 & 7,430 & 8,010 & 10,800 & 13,700 \\
\hline Equities ratio (private/public) & 2.08 & 1.67 & 1.18 & 0.77 & 0.98 & 0.89 & 1.08 \\
\hline \multicolumn{8}{|l|}{ Profits } \\
\hline Pretax profits PP & 335 & 433 & 460 & 543 & 787 & 842 & 1,480 \\
\hline After tax profits SC & 266 & 287 & 341 & 489 & 677 & 696 & 863 \\
\hline Profits - RE PP [3] & 268 & 347 & 368 & 434 & 629 & 673 & 1,180 \\
\hline After tax profits - RE SC & 175 & 194 & 246 & 351 & 479 & 530 & 641 \\
\hline \multicolumn{8}{|l|}{ LABOR INCOME } \\
\hline Paid wages, total & 141 & 191 & 246 & 292 & 331 & 336 & 419 \\
\hline $\mathrm{PP}$ & 65.4 & 79.5 & 110 & 133 & 124 & 147 & 204 \\
\hline $\mathrm{SC}$ & 75.5 & 112 & 136 & 159 & 212 & 193 & 224 \\
\hline Unpaid wages, total & 179 & 184 & 205 & 225 & 268 & 301 & 387 \\
\hline $\mathrm{PP}$ & 152 & 148 & 181 & 172 & 214 & 245 & 334 \\
\hline $\mathrm{SC}$ & 27 & 36 & 24 & 53 & 54 & 56 & 53 \\
\hline \multicolumn{8}{|l|}{ Profits - RE - unpaid wages } \\
\hline $\mathrm{PP}$ & 116 & 199 & 187 & 262 & 415 & 427 & 846 \\
\hline $\mathrm{SC}$ & 148 & 158 & 222 & 298 & 425 & 474 & 588 \\
\hline \multicolumn{8}{|l|}{ Statistics From CRSP } \\
\hline \multicolumn{8}{|l|}{ Equity Statistics } \\
\hline $\begin{array}{l}\text { Total Public Equity } \\
{[4,5]}\end{array}$ & $\begin{array}{c}3,306 \\
(3,292)\end{array}$ & $\begin{array}{c}4,396 \\
(4,376)\end{array}$ & $\begin{array}{c}6,785 \\
(6,734)\end{array}$ & $\begin{array}{c}13,288 \\
(13,217)\end{array}$ & 13,829 & 16,458 & 19,851 \\
\hline Public equity x $0.7[6]$ & 2,314 & 3,078 & 4,750 & 9,301 & 9,681 & 11,521 & 13,896 \\
\hline
\end{tabular}


Table 1: The Aggregate Statistics of Private and Public Equity (1989-2007), \$ bln. (continued)

\begin{tabular}{|c|c|c|c|c|c|c|c|}
\hline Survey year & 1989 & 1992 & 1995 & 1998 & 2001 & 2004 & 2007 \\
\hline \multicolumn{8}{|l|}{ StATISTICS FROM CRSP } \\
\hline $\begin{array}{l}\text { DiVIDEND INCOME OF } \\
\text { PUBLIC CORPORATIONS [7] }\end{array}$ & 66.4 & 69.2 & 100.0 & 98.3 & 108.0 & 107.0 & 148.0 \\
\hline \multicolumn{8}{|l|}{ StATISTICS FROM FFA/NIPA } \\
\hline \multicolumn{8}{|l|}{ Private Equity Values } \\
\hline Equity in noncorporate business [8] & 2,966 & 2,980 & 3,487 & 4,121 & 4,821 & 6,359 & 8,347 \\
\hline $\begin{array}{l}\text { Minus value of } 1-4 \text { family rental } \\
\text { properties }[9]\end{array}$ & 916 & 982 & 1,109 & 1,235 & 1,441 & 1,756 & 1,991 \\
\hline $\begin{array}{l}\text { Equals market value of proprietorships } \\
\text { and partnerships }\end{array}$ & 2,050 & 1,998 & 2,377 & 2,886 & 3,380 & 4,602 & 6,356 \\
\hline \multicolumn{8}{|l|}{$\mathrm{S}$ and $\mathrm{C}$ corporations, market value } \\
\hline With estate multiplier $=2[10]$ & 1,412 & 1,662 & 1,921 & 2,540 & 2,098 & 2,535 & - \\
\hline With estate multiplier $=3$ & 2,117 & 2,433 & 2,887 & 3,811 & 3,147 & 3,803 & - \\
\hline \multicolumn{8}{|l|}{ INCOME AND DIVIDENDS } \\
\hline $\begin{array}{l}\text { Proprietors' income [11] } \\
\text { Adjusted proprietors' income }\end{array}$ & 363.3 & 427.6 & 492.1 & 627.8 & 771.9 & 911.6 & 1056.2 \\
\hline Minus retained earnings $[12,13]$ & 187.7 & 216.3 & 283.3 & 514.6 & 514.7 & 557.3 & 678.1 \\
\hline $\begin{array}{l}\text { Dividends, S and C private } \\
\text { corporations [14] }\end{array}$ & 165.2 & 177.2 & 249.0 & 387.6 & 406.4 & 466.0 & - \\
\hline $\begin{array}{l}\text { PUBLIC EQUITY STATISTICS ON } \\
\text { NEW ISSUES AND TAKEOVERS }\end{array}$ & & 1992 & 1995 & 1998 & 2001 & 2004 & 2007 \\
\hline SDC M \& A equity adj. [15] & & 284 & 442 & 846 & 1,162 & 1,061 & 1,941 \\
\hline New issues of public equity [16] & & 40 & 75 & 108 & 164 & 63 & 94 \\
\hline
\end{tabular}

Note 1: For private equity statistics, s.e. refers to standard errors.

Note 2: This revision is as described in the text.

Note 3: RE refers to retained earnings.

Note 4: The market values for CRSP are obtained from the WRDS version of the CRSP Monthly Stock Market indices database and correpond to the variable "Total Market Value." The variable refers to the monthly total market value for a given market for all non-ADR securities with valid prices. The values reported are those for the end of the calendar year.

Note 5: The values in brackets are those originally reported in Moskowitz and Vissing-

Jørgensen (2002). The small discrepancy can be atributed to infrequent minor revisions of CRSP.

Note 6: This is the CRSP value of public equity held by the household sector.

Note 7. Dividend distributions of publicly traded corporations include only distributions from current net income and do not include liquidating and other distributions. 
Table 1: The Aggregate Statistics of Private and Public Equity (1989-2007), \$ bln. (continued)

Note 8: These numbers refer to net worth of noncorporate business and owners' equity

in farm business, and unincorporated security brokers and dealers, as reported in the FFA

balance sheets of households and nonprofit organizations.

Note 9: These values come from the BEA Detailed Data for Fixed Assets and Consumer

Durables "Residential Detailed Estimates" files. They represent values of net stocks

in 1-4 family rental properties of households, sole proprietors and partnerships, and

nonprofit organizations, net of depreciation.

Note 10: These numbers are constructed using SOI files "Estate Tax Returns Filed for "Year"

Decedents: Gross Estate by Type of Property." Multipliers 2 and 3 are applied to values of

closely held stock at date of death (value times 2 or 3, accordingly). Moskowitz and Vissing-

Jørgensen's (2002) original numbers come from tax files by year of filing not year of death. The

values for 2007 are left blank as the SOI tax files for this year have not yet been posted.

Note 11: These numbers correspond to the series "Proprietors' income incl. inventory

valuation (IVA) and capital consumption (CCAdj.) adjustments" as reported in NIPA

Table 1.13, line 14 or Table 1.12, line 9 .

Note 12: Adjusted proprietors' income refers to proprietors' income adjusted for a constant annual percentage of tax misreporting as in Moskowitz and Vissing-Jørgensen

(2002). It assumes that every $\$ 1$ of profits reported to the IRS corresponds to $\$ 1.75$ of "true"

profits. This adjustment is available only for nonfarm proprietors' income as reported in

NIPA Table 7.14, line 1 (BEA does not provide raw data from the IRS for the noncorporate farm

sector), so for noncorporate farm income I use reported NIPA income instead.

The tax misreporting adjustment applies to income without IVA and CCAdj. I add back IVA

adjustment, but not CCAdj. to get a measure of the actual profit flow to proprietors. Then

the total adjusted proprietors' income is the sum of the NIPA farm income with IVA adjustment

(Table 1.12, line 32), and nonfarm income constructed as above.

Note 13: As in Moskowitz and Vissing-Jørgensen (2002), retained earnings adjustment is

given by the sum of capital expenditures, net acquisition of financial assets less net increase

in financial liabilities, and proprietors' net investment.

Note 14: These are obtained as a difference between NIPA/FFA total corporate dividends

and CRSP dividends of publicly traded corporations. The value for 2007 cannot be

constructed as the total dividends from NIPA/FFA for this year are unavailable.

Note 15: Values of M\&A adjustment are aggregated for the three-year periods 1990-92,

1993-95, 1996-98, 1999-2001, 2002-04, 2005-07. These values reflect movements

in and out of public equity between the survey years.

Note 16: As MVJ, in construction of private equity returns with IPO adjustment, I use statistics from Ritter

published on his web-site: reported by Jay Ritter on his web-site: http://bear.cba.ufledu/ritter/Moneybyyear.pdf.

As in the case of M\&A adjustment, values are aggregated over the three-year intervals. 
TABle 2: The Returns to Private Equity (SCF, 1989-2007)

\begin{tabular}{|c|c|c|c|c|c|c|c|}
\hline & 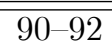 & (93-95 & $\begin{array}{l}96-98 \\
\end{array}$ & 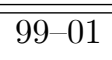 & 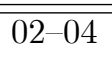 & $05-07$ & 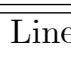 \\
\hline \multicolumn{8}{|c|}{ Total Private Equity in SCF } \\
\hline \multicolumn{8}{|c|}{ UNADJUSTED RETURNS } \\
\hline ALL & 17.4 & 21.9 & 26.4 & 27.7 & 22.7 & 29.0 & 1 \\
\hline PP & 15.7 & 19.0 & 26.3 & 30.3 & 23.7 & 39.5 & 2 \\
\hline $\mathrm{SC}$ & 19.5 & 25.0 & 26.5 & 25.5 & 21.8 & 19.1 & 3 \\
\hline \multicolumn{8}{|c|}{ INCOME TAXES } \\
\hline ALL & 15.8 & 20.7 & 25.4 & 26.5 & 21.8 & 28.5 & 4 \\
\hline $\mathrm{PP}$ & 15.7 & 19.0 & 26.3 & 30.3 & 23.7 & 39.5 & 5 \\
\hline $\mathrm{SC}$ & 16.0 & 22.5 & 24.5 & 23.4 & 20.2 & 18.1 & 6 \\
\hline \multicolumn{8}{|c|}{ RETAINED EARNINGS } \\
\hline ALL & $\begin{array}{c}12.3 \\
(12.3)\end{array}$ & $\begin{array}{c}17.2 \\
(17.0)\end{array}$ & $\begin{array}{c}22.1 \\
(22.2)\end{array}$ & 23.1 & 18.9 & 25.8 & $\begin{array}{l}7 \\
8\end{array}$ \\
\hline $\mathrm{PP}$ & $\begin{array}{c}12.8 \\
(12.6)\end{array}$ & $\begin{array}{c}15.7 \\
(15.6)\end{array}$ & $\begin{array}{c}23.1 \\
(23.0)\end{array}$ & 27.1 & 20.6 & 36.7 & $\begin{array}{c}9 \\
10\end{array}$ \\
\hline $\mathrm{SC}$ & $\begin{array}{c}11.7 \\
(12.0)\end{array}$ & $\begin{array}{c}18.7 \\
(18.5)\end{array}$ & $\begin{array}{c}21.1 \\
(21.4)\end{array}$ & 19.8 & 17.2 & 15.4 & $\begin{array}{l}11 \\
12\end{array}$ \\
\hline \multicolumn{8}{|c|}{ LABOR INCOME } \\
\hline ALL & $\begin{array}{c}8.2 \\
(8.2)\end{array}$ & $\begin{array}{c}13.3 \\
(12.7)\end{array}$ & $\begin{array}{c}18.6 \\
(18.4)\end{array}$ & 20.2 & 16.2 & 23.5 & $\begin{array}{l}13 \\
14\end{array}$ \\
\hline $\mathrm{PP}$ & $\begin{array}{c}6.5 \\
(6.4)\end{array}$ & $\begin{array}{c}9.2 \\
(9.4)\end{array}$ & $\begin{array}{c}16.9 \\
(15.9)\end{array}$ & 22.1 & 16.0 & 33.0 & $\begin{array}{l}15 \\
16\end{array}$ \\
\hline $\mathrm{SC}$ & $\begin{array}{c}10.2 \\
(10.9)\end{array}$ & $\begin{array}{c}17.5 \\
(16.9)\end{array}$ & $\begin{array}{c}20.0 \\
(20.6)\end{array}$ & 18.6 & 16.3 & 14.6 & $\begin{array}{l}17 \\
18\end{array}$ \\
\hline \multicolumn{8}{|c|}{ FIRM BIRTH } \\
\hline ALL & $\begin{array}{c}7.0 \\
(7.5)\end{array}$ & $\begin{array}{c}11.8 \\
(11.6)\end{array}$ & $\begin{array}{c}16.1 \\
(16.4)\end{array}$ & 18.2 & 14.5 & 17.4 & $\begin{array}{l}19 \\
20\end{array}$ \\
\hline $\mathrm{PP}$ & 5.3 & 7.5 & 13.8 & 20.4 & 13.9 & 26.3 & 21 \\
\hline $\mathrm{SC}$ & 9.2 & 16.3 & 18.0 & 16.4 & 15.0 & 9.0 & 22 \\
\hline \multicolumn{8}{|c|}{ IPO [1] } \\
\hline ALL & $\begin{array}{c}7.4 \\
(7.8)\end{array}$ & $\begin{array}{c}12.3 \\
(12.1)\end{array}$ & $\begin{array}{c}16.7 \\
(17.0)\end{array}$ & 18.8 & 14.7 & 17.6 & $\begin{array}{l}23 \\
24\end{array}$ \\
\hline
\end{tabular}


Table 2: The Returns to Private Equity (1989-2007) (continued)

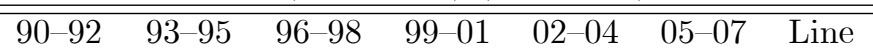

Total Private Equity in SCF

$\mathrm{M} \& \mathrm{~A}$

ALL

$\begin{array}{ccccccc}9.6 & 15.4 & 21.4 & 23.5 & 18.0 & 22.3 & 25 \\ (8.2) & (13.0) & (19.4) & & & & 26\end{array}$

Non-actively Managed Private

Equity in SCF [2]

All owners

NON-ACTIVE OWNERS

$\begin{array}{lllllll}37.5 & 10.5 & 26.8 & 15.1 & 15.4 & 22.7 & 27\end{array}$

$\begin{array}{lllllll}36.0 & 21.7 & 40.2 & 13.3 & 5.5 & 36.8 & 28\end{array}$

Private Equity in FFA/NIPA PP

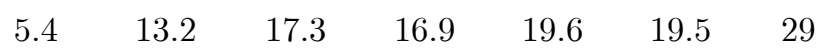

Public Equity in CRSP

CRSP VALUE-WGTD INDEX UPDATED [3]

$\begin{array}{lllllll}11.0 & 14.5 & 24.5 & -0.4 & 6.0 & 10.2 & 30\end{array}$

CRSP S\&P INDEX

HOLDING RETURN

$(24.7)$

$\begin{array}{lll}7.2 & 11.2 \quad 25.9\end{array}$

$-2.3 \quad 1.8$

S\&P INDEX, ShILler

7.9

12.

26.1

$-4.2$

$0.1 \quad 5.5$

33

Public Equity in SCF

\begin{tabular}{lccccccc} 
RETURN & 11.2 & 20.4 & 28.5 & 16.4 & -0.8 & 9.2 & 34 \\
RETURN REVISED & 11.2 & 20.4 & 28.5 & 3.8 & 11.5 & 9.2 & 35 \\
\hline
\end{tabular}

Note 1: IPO adjustment uses Jay Ritter's data.

Note 2: Category "all owners" refers to entrepreneurs with both actively and passively managed businesses; "non-active owners" refers to entrepreneurs with passive management role only.

Note 3: For the CRSP value-weighted index, returns in brackets are those originally reported in Moskowitz and Vissing-Jørgensen (2002). 
TABle 3: Public Equity Market Values and Returns (1998-2007)

\begin{tabular}{|c|c|c|c|c|c|c|}
\hline Year & 1998 & 1999 & 2000 & 2001 & 2002 & Line \\
\hline CRSP MARKET VALUE, BLN. \$ & 13,288 & 17,009 & 15,575 & 13,829 & 11,034 & 1 \\
\hline CRSP INDEX RETURN, \% & 22.3 & 25.3 & -11.1 & -11.3 & -20.8 & 2 \\
\hline CRSP S\&P RETURN, \% & 26.7 & 19.5 & -10.1 & -13.0 & -23.4 & 3 \\
\hline Year & 2003 & 2004 & 2005 & 2006 & 2007 & Line \\
\hline CRSP MARKET VALUE, BLN. \$ & 14,585 & 16,458 & 17,384 & 19,548 & 19,851 & 1 \\
\hline CRSP INDEX RETURN, \% & 33.1 & 13.0 & 7.3 & 16.2 & 7.3 & 2 \\
\hline CRSP S\&P RETURN, \% & 26.4 & 9.0 & 3.0 & 13.6 & 3.5 & 3 \\
\hline
\end{tabular}

TABLE 4: Private Equity Industry Characteristics and Returns (1989-2007)

\begin{tabular}{|c|c|c|c|c|c|c|c|}
\hline Year & $\overline{990-92}$ & $93-95$ & 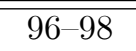 & $\overline{999-01}$ & "02-04 & 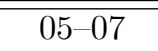 & Line \\
\hline \multicolumn{8}{|l|}{ Aggregates, mln. $\$$} \\
\hline Total resources & 61,841 & 137,174 & 362,162 & 802,647 & 446,440 & $1,390,315$ & 1 \\
\hline Total investments & 13,461 & 22,789 & 67,812 & 287,907 & 120,923 & 165,859 & 2 \\
\hline \multicolumn{8}{|l|}{ Returns, \% } \\
\hline \multicolumn{8}{|l|}{ ALL PRIVATE EQUITY } \\
\hline Pooled IRR & 13.6 & 14.9 & 16.7 & 18.0 & 14.2 & 14.1 & 3 \\
\hline 1-yr horizon IRR & 9.3 & 23.6 & 25.4 & 14.7 & 6.9 & 13.0 & 4 \\
\hline \multicolumn{8}{|l|}{ Venture Capital } \\
\hline Pooled IRR & 9.8 & 12.0 & 14.9 & 19.2 & 16.4 & 15.9 & 5 \\
\hline \multicolumn{8}{|l|}{ Buyout Funds } \\
\hline Pooled IRR & 21.3 & 19.6 & 19.8 & 17.3 & 12.5 & 13.3 & 6 \\
\hline
\end{tabular}


Table 5: Private Equity (PE) and Own-Company Public Stock Ownership

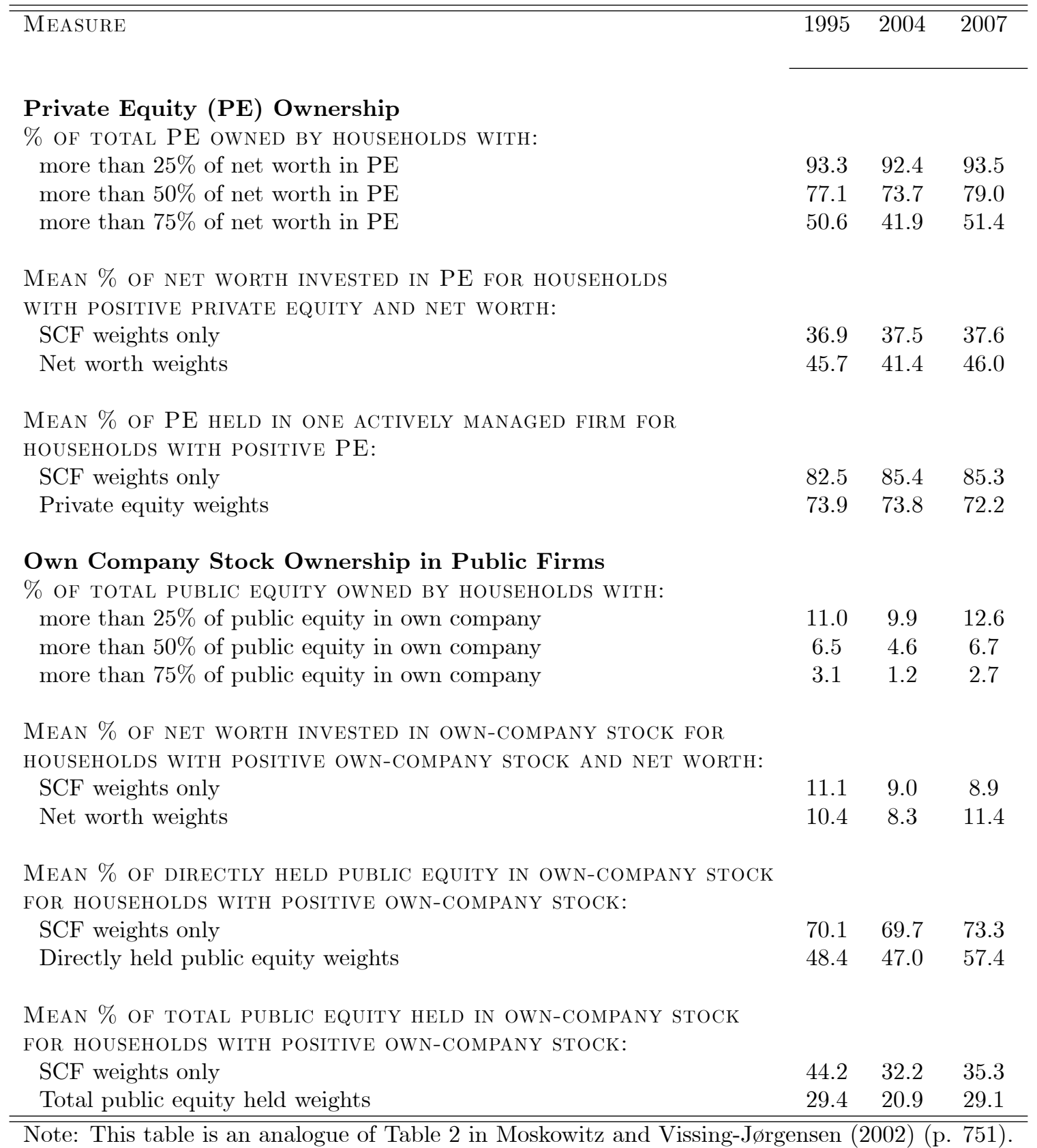


Table 6: Summary Statistics on Entrepreneurs from the Survey of Consumer Finances

\begin{tabular}{|c|c|c|c|c|c|c|c|}
\hline \multicolumn{3}{|l|}{ Section A } & \multicolumn{5}{|c|}{ Percentile } \\
\hline Characteristic & Mean & Std. dev. & 10th & 25 th & 50 th & 75 th & 90th \\
\hline SCF1995 & & & & & & & \\
\hline Entrepreneur age & 46.5 & 12.6 & 31 & 37 & 45 & 54 & 65 \\
\hline Firm age & 11.9 & 11.6 & 2 & 4 & 8 & 16 & 26 \\
\hline Private equity value, $\$$ ths. & 289.3 & $1,664.9$ & 0 & 5.0 & 30.0 & 129.0 & 481.0 \\
\hline Sales, $\$$ ths. & $6,994.7$ & 217,000 & 0 & 4.2 & 30.0 & 130.0 & 700.0 \\
\hline Profits, $\$$ ths. & 94.2 & $1,646.7$ & 0 & 0.5 & 6.5 & 29.0 & 80.0 \\
\hline Net worth, $\$$ ths. & 774.5 & $3,365.7$ & 32.0 & 80.6 & 182.0 & 489.6 & $1,337.7$ \\
\hline Share of firm, \% [1] & 86.5 & 26.4 & 100 & 1000 & 100 & 100 & 100 \\
\hline Employees [2] & 12.1 & 123.8 & 1 & 1 & 2 & 4 & 12 \\
\hline SCF 2007 & & & & & & & \\
\hline Entrepreneur age & 49.4 & 11.9 & 34 & 41 & 49 & 58 & 65 \\
\hline Firm age & 12.7 & 10.6 & 2 & 4 & 10 & 18 & 28 \\
\hline Private equity value, $\$$ ths. & 751.9 & $4,592.4$ & 0 & 11.0 & 80.0 & 350.0 & $1,200.0$ \\
\hline Sales, $\$$ ths. & $6,521.6$ & $101,000.0$ & 1.2 & 15.0 & 70.0 & 373.0 & $1,500.0$ \\
\hline Profits, $\$$ ths. & 147.2 & 994.5 & 0 & 3.0 & 20.0 & 75.0 & 200.0 \\
\hline Net worth, $\$$ ths. & $2,067.0$ & $8,291.6$ & 64.0 & 178.3 & 515.8 & $1,519.0$ & $4,647.8$ \\
\hline Share of firm, $\%$ & 82.9 & 29.2 & 33 & 50 & 100 & 100 & 100 \\
\hline Employees & 28.5 & 272.9 & 1 & 1 & 2 & 6 & 15 \\
\hline
\end{tabular}

TABle 6: Summary Statistics on Entrepreneurs from the Survey of Consumer Finances

\begin{tabular}{lc}
\hline \hline Section B & \\
SCF 2007 & $\% \mathrm{PE}$ \\
INDUSTRY & 10.2 \\
Agriculture [3] & 17.5 \\
Construction/mining [4] & 6.5 \\
Manufacturing & 13.7 \\
Retail, wholesale [5] & 14.7 \\
FIRE/communications [6] & 37.4 \\
Services [7] & \\
\hline
\end{tabular}

Note 1: The ownership share refers to the first (main) actively managed business of the household.

Note 2: The number of employees includes entrepreneurs working in the business.

Note 3: This category includes: agriculture, forestry, fishing, hunting, and veterinary and landscaping services.

Note 4: Oil and gas extraction, coal mining, quarrying, and supporting services for mining and construction.

Note 5: Wholesale and retail trade, restaurants, and food services.

Note 6: Finance and insurance, real estate (FIRE), automotive rental and leasing, software publishing, data processing, automotive repair and maintenance.

Note 7: Commercial, industrial, and other intangible asset rental and leasing; employment and business support services; broadcasting and telecommunications; other administrative and support services; health, education, and social services; arts and entertainment services; recreation, accommodation, and food services; personal services, etc. 
Table 7: Merger and Acquisition Activity in Private and Public Firms (1989-2007), \$ billion

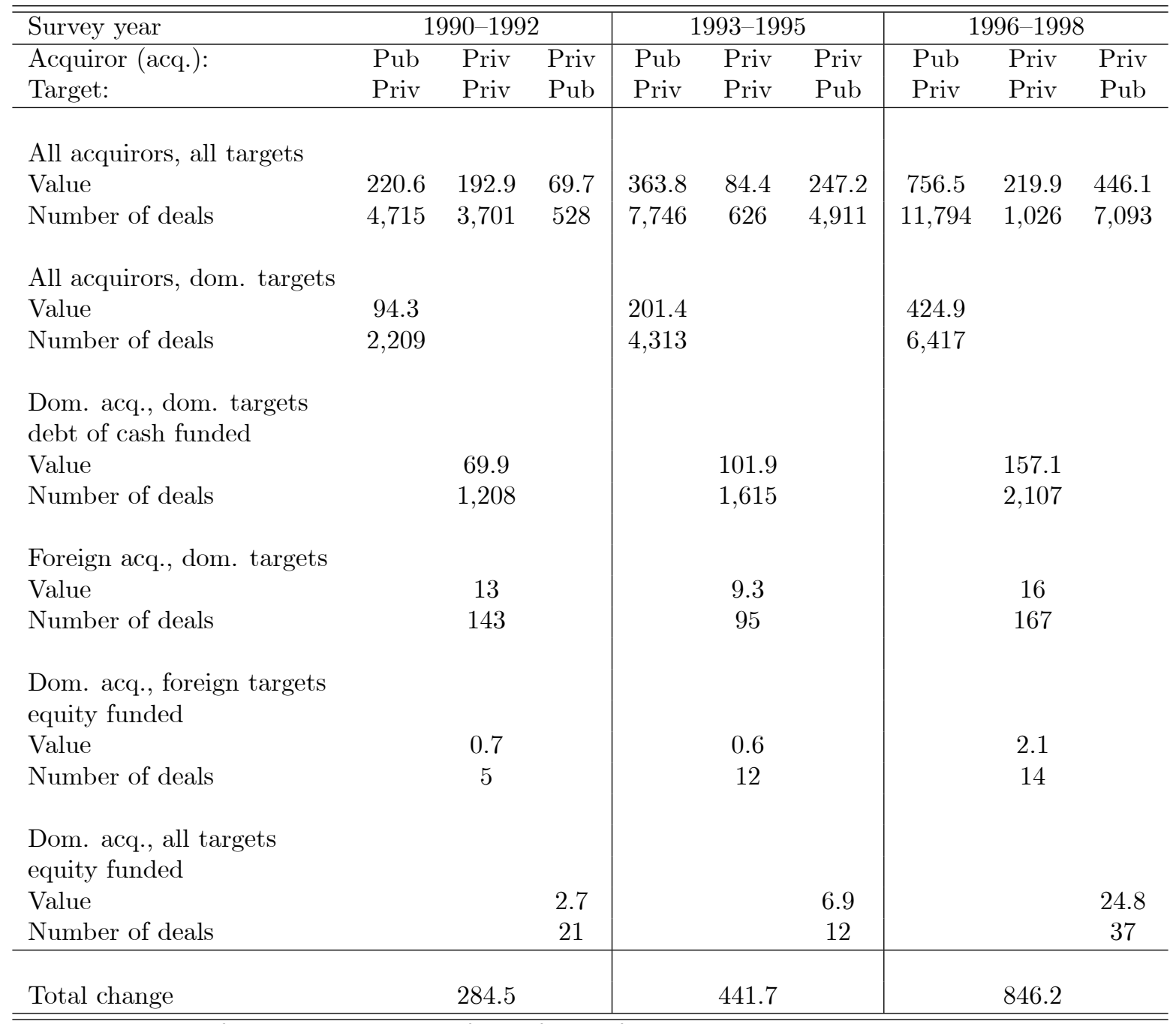

Note 1: Dom. refers to domestic, and for. refers to foreign. 
Table 7: Merger and Acquisition Activity in Private and Public Firms (1989-2007), \$ bln. (continued)

\begin{tabular}{|c|c|c|c|c|c|c|c|c|c|}
\hline \multirow{3}{*}{$\begin{array}{l}\text { Survey year } \\
\text { Acquiror: } \\
\text { Target: }\end{array}$} & \multicolumn{3}{|c|}{ 1999-2001 } & \multicolumn{3}{|c|}{$2002-2004$} & \multicolumn{3}{|c|}{$2005-2007$} \\
\hline & Pub & Priv & Priv & Pub & Priv & Priv & Pub & Priv & Priv \\
\hline & Priv & Priv & Pub & Priv & Priv & Pub & Priv & Priv & Pub \\
\hline \multicolumn{10}{|c|}{ All acq., all targets } \\
\hline Value & 1,126 & 400.9 & 635.4 & 723.6 & 287.3 & 470 & 1,241 & 1,327 & 1,488 \\
\hline Number of deals & 11,588 & 1,590 & 8,133 & 9,025 & 1,253 & 7,592 & 12,765 & 1,606 & 9,670 \\
\hline \multicolumn{10}{|c|}{ All acq., dom. targets } \\
\hline Value & 534.1 & & & 330.1 & & & 497.4 & & \\
\hline Number of deals & 4,670 & & & 3,056 & & & 3,866 & & \\
\hline \multicolumn{10}{|c|}{$\begin{array}{l}\text { Dom. acq., dom. targets } \\
\text { debt of cash funded }\end{array}$} \\
\hline Value & & 181 & & & 230.8 & & & 457.7 & \\
\hline Number of deals & & 1,966 & & & 1,959 & & & 2,308 & \\
\hline \multicolumn{10}{|c|}{ For. acq., dom. targets } \\
\hline Value & & 22.4 & & & 18.7 & & & 82.2 & \\
\hline Number of deals & & 222 & & & 150 & & & 265 & \\
\hline \multicolumn{10}{|c|}{$\begin{array}{l}\text { Dom. acq., for. targets } \\
\text { equity funded }\end{array}$} \\
\hline Value & & 0.4 & & & 2.8 & & & 2 & \\
\hline Number of deals & & 19 & & & 11 & & & 8 & \\
\hline \multicolumn{10}{|c|}{$\begin{array}{l}\text { Dom. acq., all targets } \\
\text { equity funded }\end{array}$} \\
\hline Value & & & 7.9 & & & 9.3 & & & 45.1 \\
\hline Number of deals & & & 33 & & & 14 & & & 10 \\
\hline Total change & & 1,162 & & & 1,061 & & & 1,941 & \\
\hline
\end{tabular}


TABle 8: Robustness Checks

\begin{tabular}{|c|c|c|c|c|c|c|c|}
\hline & 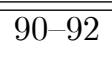 & $\overline{93-95}$ & 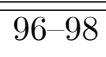 & $\overline{99-01}$ & $\overline{02-04}$ & 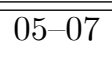 & Line \\
\hline \multicolumn{8}{|c|}{ Total Private Equity in SCF } \\
\hline \multicolumn{8}{|c|}{ MVJ Assumptions } \\
\hline ALL EQUiTy & 9.6 & 15.4 & 21.4 & 23.5 & 18.0 & 22.3 & 1 \\
\hline \multicolumn{8}{|c|}{$\begin{array}{l}\text { Alternative Assumptions } \\
\text { Noncorporate labor income [1] }\end{array}$} \\
\hline AlL EQUity & 8.7 & 14.5 & 20.4 & 22.6 & 17.5 & 21.7 & 2 \\
\hline \multicolumn{8}{|c|}{$\begin{array}{l}\text { Production function income shares } \\
\text { for noncorporate income and [1], [2] }\end{array}$} \\
\hline ALL EQUITY & 8.3 & 13.9 & 19.9 & 21.6 & 16.2 & 20.0 & 3 \\
\hline \multicolumn{8}{|c|}{ PUBLIC EQUITY RETURNS } \\
\hline CRSP [3] & 11.0 & 14.5 & 24.5 & -0.4 & 6.0 & 10.2 & 4 \\
\hline
\end{tabular}

Note 1: With this adjustment, both reported and unreported imputed wages for proprietors and partners are subtracted from net income to construct their returns.

Note 2: This adjustment is the same as [1] above but uses the time-invariant share of labor income in total net income for the labor adjustment.

Note 3: Public equity returns are included in the table to confirm that the main result of the paper remains unchanged with alternative assumptions on labor adjustment. 